\title{
A REVIEW OF TRIDAX PROCUMBENS AND ITS ACTIVITY
}

\author{
Sabarinath.K, Sandhiya.S, Ishwarya.R, Logeshwaran.V, Kousalya.N \\ Postgraduate student \\ Department of Biotechnology, Dr. N.G.P. Arts and Science College (Autonomous) \\ Coimbatore-48 \\ Arun. $\mathrm{P}$ \\ Assistant professor \\ Department of Biotechnology, Dr. N.G.P. Arts and Science College (Autonomous) \\ Coimbatore-48
}

\begin{abstract}
Tridax procumbens (T. procumbens) is also known as coat button or tridax daisy. It is the widespread weed and also a pest plant in tropical and subtropical. $T$. procumbens was used as a traditional medicine in wound healing, antifungal, antibacterial, insect repellent all over the world. The raw leave extract of $T$. procumbens is used as a best for wound healing as a Ayurvedic medicine in India.
\end{abstract}

Keywords - Tridax procumbens, Ayurvedic medicine

\section{INTRODUCTION}

Tridax procumbens (T. procumbens) is belong to Asteraceae family. It's a annual and perianal weed, widespread throughout India. It has bisexual flower with white headed flower and the whole plant has the activity of wound healing, antifungal, antibacterial, insect repellent, and antimalarial. The main aim of the review is to enrich the knowledge about Tridax procumbens and its activity.

\section{SCIENTIFIC CLASSIFICATION \\ Kingdom : Plantae \\ Order : Asterales \\ Family : Asteraceae \\ Genus : Tridax \\ Species : procumbens}

\section{TRADITIONAL USE}

The whole plant $T$. procumbens is used as a raw medicine for protozoal infection, chronic ulcer, diabetes, insect repellent, wound healing, and inflammation, jaundice, anti-malarial, antibacterial, and anti-fungal. Flavonoids which found in the whole tridax plant act as a best anticoagulants and wound healing.

\section{ANTICOAGULATION ACTIVITY}

$200 \mathrm{mg} / \mu \mathrm{g}$ of $T$. procumbens is injected to rabbit, result in prolongation of clottind time by reduce the production of heparin.

\section{WOUND HEALING ACTIVITY}

Extraction of $T$. procumbens increased the lysyl oxidase activity, protein content, and breaking strength which helps in promoting wound healing. It increased the interaction between epidermal and dermal cells.

The tridax extract also increased the glycosaminoglycan level as it increased the protein and nucleic acid content.

\section{ANTIOXIDANT ACTIVITY}

Methanol was used as a solvent to extract the aerial part of the plant and subjected to DPPH assay. The extraction on the solvents Ethyl acetate and n-butanol showed better antioxidant result when compared to the standard Ascorbic acid.

The ethanolic extract of tridax shows $96.70 \%$ of antioxidant where standard gallic acid and ascorbic acid shows $92.92 \%$ and $94.81 \%$ respectively.

\section{INSECTICIDAL ACTIVITY}

The oil of tridax is used as strong insect repellent against house flies, mosquito's larvae, cockroaches, and Dysder cussimile. It is observed that tridax is neither attacked by insects and cattles.

\section{ANTIMALARIAL ACTIVITY}

The oil of tridax shows relatively high antimalarial activity against Anopheles stephensi when compared to their two plants I. cairica, $M$. charantia. Clear dosage relationship 


\section{International Journal of Engineering Applied Sciences and Technology, 2019 \\ Vol. 4, Issue 8, ISSN No. 2455-2143, Pages 192-194 \\ Published Online December 2019 in IJEAST (http://www.ijeast.com)}

was established in all essential oils, with highest concentration of $6 \%$.

\section{HAIR GROWTH PROMOTING ACTIVITY}

The ethanolic extract of aerial part of the plant was administered to albino rat as $10 \%$ ointment and also as orally $100 \mathrm{~g} / \mathrm{kg}$ for about 20 days and the both treat showed good results. The petrol fraction of the extract shows a more effective when compared to other fraction extract.

\section{ANTIPROTOZOAL ACTIVITY}

Extract of 13 plant was subjected against protozoal infection, were evaluated in vitro against epimastigotes and tripogmastiogotes and in vivo against tripogmastiogotes of that tridax shows best antiprotozoal activity.

\section{LEISHMANICIDAL ACTIVITY}

The Methanol extracts prepared from different parts of 18 plants collected and evaluated in an in vitro bioassay for leishmanicidal activity against Leishmania mexicana promastigotes. The ten most potent plant extracts (IC50 < 50 $\mu \mathrm{g} / \mathrm{ml}$ ) were Aphelandra scabra leaves, Byrsonima bucidaefolia bark, Byrsonima crassifolia bark, Clusia flava leaves, Cupania dentata bark, Diphysa carthagenensis leaves, Dorstenia contrajerva whole plant, Milleria quinqueflora roots, Tridax procumbens whole plant, and Vitex gaumeri bark.

\section{ANTI-INFLAMMATORY ACTIVITY}

In the carrageenan induced Oedema model, inhibition of Oedema was comparable in $200 \mathrm{mg} / \mathrm{kg}$ Tridax procumbens and $50 \mathrm{mg} / \mathrm{kg}$ ibuprofen treatment and the specific activity of the enzyme gamma glutamyl transpeptidase was comparable in the Tridax procumbens, ibuprofen and aspirin at $200 \mathrm{mg} / \mathrm{kg}$

\section{CONCLUSION}

Although Tridax procumbens is type of weed plant it has many useful above discussed properties and activities. The above properties clearly show that it has both immunological and pharmaceutical properties. Some of the beneficial activity are yet to clear about this plant.

\section{ACKNOWLEDGEMENT}

The author expresses their gratitude towards the host Institution Dr.N.G.P. Arts and Science college, Management, Principal, Deans, Head of the department, guide and other all other staffs of Department of biotechnology for rendering all the facilities and support. Communication no: DrNGPASC 2019-20 BS019.

\section{REFERENCE}

[1] Agrawal SS, Talele GS and Surana S (2009). Antioxidant activity from fractions from Tridax procumbens. Journal of Pharmacy Research, 2(1): 71-73

[2] Ali ME and Ramachandram R (2001). A new flavonoid from the aerial parts of Tridax procumbens. Fitoterapia, 72(3): 313-315.

[3] Ali MS and Jahangir M (2002). A Bis-Bithiophene from Tridax procumbens L. (Asteraceae). Nat. Prod. Res., 16(4): 217-221.

[4] Caceres A, Berger I, Barrientos AC, Caceres A, Hernandez M, Rastrelli L, Passreiter CM and Kubelka W (1986). Plants used in Guatemala for the treatment of protozoal infections: II. Activity of extracts and fractions of five Guatemalan plants against Trypanosoma cruzi. Journal of Ethnopharmacology, 62, 107-115.

[5] Devi Vimla and Suneeta A (1990). J. of Research and Education in Indian Medicine, 9(4): 39-41.

[6] Gadre A and Gabhe SY (1992). Identification of some sterols of Tridax procumbens by GC-MS. Indian J. Pharm. Scien., 55(5): 191-192.

[7] Gupta S, Yadava JNS and Tondon JS (1993). Antisecretory (anti-diarrheal) activity of Indian medicinal plants against E. coli enterotoxin- induced secretion in rabbit and guinea pig ileal loop models. International J. of Pharmacology, 31(3): 198-204.

[8] Kanungo S, Mohanty S, Das M, Patnaik J and Mohanty M (1995). A study of the effects of Tridax procumbens Linn. on normal and heparin induced prolongation of clotting time in rabbits. Indian Journal of Pharmacology, 27(1): 63.

[9] Margaret I, Reddy PS and Kaiser J (1998). Antiinflammatory profile of Tridax Procumbens in animal and fibroblast cell models. Phytotherapy Research, 12(4): 285-287.

[10] Morales C, Gomez-Serranillos MP, Iglesias I, Villar AM and Caceres A (2001). Preliminary screening of five ethnomedicinal plants of Guatemala. Farmaco., 56(5-7): 523-526.

[11] Oommachan M (1976). The Flora of Bhopal. I Edn. J. K. Jain Brothers, Bhopal, 192-199.

[12] Oudhia P (1999). Medicinal weeds in rice fields of Chhattisgarh (India). International Rice Research Note, 24(1): 40-41.

[13] Pathak AK and Dixit VK (1991). Hepatoprotective activity of Tridax-procumbens part I. Fitoterapia, 62: 307-314.

[14] Pathak AK. and Dixit VK (1988). Insecticidal and insect repellent activity of essential oils of Tridax procumbens and Cyathoclineiyrata. Fitoterapia, 59: 211-214. 
[15] Peraza-Sanchez SR, Cen-Pacheco F, Noh-Chimal A, May-Pat F, Sima-Polanco P, Dumonteil E, GarciaMiss MR and Mut-Martin M (2007). Leishmanicidal evaluation of extracts from native plants of the Yucatan peninsula Fitoterapia, 78: 315-318.

[16] Perumal SR, Ignacimuthu S and Patric Raja D (1999). Preliminary screening of ethnomedicinal plants from India. J. Ethnopharmacol., 66(2): 235240.

[17] Rajkumar S and Jebanesan A (2007). Repellent activity of selected plant essential oils against the malarial fever mosquito Anopheles stephensi Trop. Biomed., 24(2): 71-5. 